\section{We urgently need more data to improve the lives of laboratory animals}

Sir - One of the tasks of the international Organisation for Economic Co-operation and Development (OECD) is to produce standardized guidelines for harmonizing national regulations. The Paris-based OECD's environmental directorate is currently preparing a draft guidance document on the recognition, assessment and use of clinical signs as humane endpoints for experimental animals used in safety evaluation (OECD Series on Testing and Assessment, N.19, www.oecd. org/ehs/test/flags.htm). Experts and interested people are invited to submit comments through national coordinators.

Comments, including ours, have been delivered to OECD in the past few weeks. But we are concerned that some important scientific and ethical issues may not be receiving the attention they deserve. On other occasions we have pointed out some shortcomings in guidelines for the care of laboratory animals. For example, the recent US National Research Council guide is more concerned with dogs than with rodents, possibly because of the influence of veterinarians, who are trained to care for pet animals, in preparing the guidelines ${ }^{1}$. Yet rodents are by far the most commonly used experimental species of mammal.

The current OECD document risks overlooking some behavioural features of laboratory animals that could help in improving their general level of welfare. To take one example, behavioural observations aid in judging the vitality of the newborn rodent pup. The degree of spatial dispersion at the nest site provides an assessment that is otherwise difficult in newborns before their eyes are open, but under current guidelines is vital to the declaration of the 'moribund' state which compulsorily precedes euthanasia. In our experience, the ultrasonic calling pattern is also highly informative.

Furthermore, refined ethological techniques (some devised in our laboratory) provide improved, lower-suffering methods for measuring the reaction of rodents toward painful stimuli ${ }^{2}$. These experimental protocols, protecting both data quality and psychophysical welfare, received substantial approval at the third international congress on alternatives in animal use, held in Bologna last summer ${ }^{3}$.

The care and maintenance of laboratory animals has to take into account the evolutionary history of the species under study. This is particularly true when the subjects are laboratory-maintained male mice or female rats, living all their lives in unnatural social settings which fairly frequently result in fighting ${ }^{4}$. The need to consider behavioural and species-specific characteristics is also relevant when primates are used as experimental animals. The European Federation of Primatology ( http://www. unipv.it/webbio/efp/efp.htm), through its primate expert group, is currently preparing a series of recommendations on minimal cage-sizes and specific environmental enrichment techniques, to be proposed to the Council of Europe.

There is still much work to do, and we urgently need more reliable behavioural data. This is particularly true for animals used for neuroscience research, where there is possibly most potential for stress and overt suffering. The ethologist's perspective will also be of great use given the explosion in use of transgenic mouse strains, some of which have unexpectedly been found to be hyperalgesic or to have abnormal levels of fear and inter-male aggressive behaviour. Enrico Alleva, Augusto Vitale Laboratory of Physiopathology of Organ and System, Istituto Superiore di Sanità, Viale Regina Elena 299, 1-00161 Rome, Italy

1. Alleva, E. \& Santucci, D. Ethology 103, 1072-1073 (1997).

2. Cirulli, F., De Acetis, L. \& Alleva, E. in Progress in the Reduction Refinement and Replacement of Animal Experimentation (eds Balls, M. et al.) (Elsevier, Amsterdam, in the press).

3. Balls, M. van Zeller, A.-M., Halder, M.(eds) Progress in the Reduction, Refinement and Replacement of Animal Experimentation (Elsevier, Amsterdam, in the press).

4. Alleva, E., Petruzzi, S. \& Ricceri, L. in Behavioural Brain Research in Naturalistic and Semi-Naturalistic Settings (eds Alleva, E. et al.) 359-374 (Kluwer, Dordrecht, 1995).

\section{Planck family paid a high price for opposing Hitler}

Sir-Your News item "German science starts facing up to its historical amnesia" should rivet the attention of the living generation of scientific workers on the tragic descent of broad sections of German science and medicine into the embrace of Hitler and Goebbels.

Under the Third Reich, 45 per cent of German physicians became Nazi party members ${ }^{2}$, and physicists of the rank of Stark and Lenard, together with the worldclass mathematician Bieberbach, robustly espoused Nazi doctrine and practice and railed against contamination of the German academy by 'Jewish physics', notably Einstein's special relativity theory ${ }^{3}$.

Unfortunately, the doctored and undoctored 1934 group photo of Max Planck which accompanies your news item may mislead readers into conceiving Max Plank himself to be a willing fraternizer with German fascism. In fact, Planck and his closest associate, Max von Laue, were among the first to assimilate and respond to Einstein's great 1905 paper. As Einstein's biographer Abraham Pais notes": "The rapidity with which special relativity became a topic of discussion is largely due to Planck's early interest".

These events in the first decade of the twentieth century were followed by at least three memorable events under the Third Reich. In 1933, during a face-to-face showdown, Planck pleaded in vain with a highly agitated Führer to stop the Nazi purge of the German academy ${ }^{5}$. In 1935 Planck officially defied Hitler by publicly commemorating Fritz Haber at the Kaiser Wilhelm Institute ${ }^{6}$. And, in 1945, the Gestapo executed Planck's last surviving child, Erwin Planck, for complicity in the Stauffenberg conspiracy to assassinate Hitler. William Steinsmith

239 Castenada Avenue, San Francisco, California 94116, USA

1. Abbott, A. Nature 403, 474 (2000).

2. The Value of the Human Being: Medicine in Germany, 1918-1945 (Ärztekammer, Berlin, 1991).

3. Nature 133, 290 (1934); 137, 93 \& 141 (1936).

4. Pais, A. Subtle is the Lord: The Science and Life of Albert Einstein 149-150 (Oxford Univ. Press, Oxford, 1982).

5. Heilbron, J. L. The Dilemmas of an Upright Man: Max Planck as a Spokesman for German Science (Univ. of California Press, Berkeley, 1986).

6. Nature 135, 216 (1935); 158, 170 (1946)

\section{How to make diplomats scientifically literate}

Sir - I read with great interest the Opinion article (Nature 404, 1; 2000) concerning attempts by the US Secretary of State, Madeleine Albright, to produce a scientifically literate State Department. Such attempts will, of course, fail in the end, since the approach being taken by Albright and State Department officials is at best inconsequential, and at worst, perverse.

Hiring an upper-echelon official merely exacerbates the already deleterious hierarchical structure that exists in the US State Department and does not achieve any objective whatsoever. The clear and obvious way to improve the 'scientific literacy' of State Department officials is, first, to remove the bias against scientists present among many diplomats in the State Department and, second, to hire more (not fewer) scientists as foreign service officers and science attachés at embassies overseas, particularly those scientists who have abundant international affairs experience, knowledge of foreign languages and expertise in global science policy.

Until the prejudiced belief that scientists somehow cannot make competent diplomats is completely removed from the US State Department, actions like Albright's are mere window-dressing.

Peter Cohen

The Herbarium, University of Michigan, Ann Arbor, Michigan 48109, USA 